\title{
CABBAGE AND VITAMIN E: THEIR EFFECT ON COLON TUMOR FORMATION IN MICE
}

\author{
NORMAN J. TEMPLE and SHUKRI M. EL-KHATIB
}

Department of Biochemistry, School of Medicine, Universidad Central del Caribe, Box 935, Cayè, Puerto Rico 00634 (Puerto Rico)

(Received 29 September 1986)

(Revised 12 December 1986)

(Accepted 16 December 1986)

\section{SUAEM AR Y}

The effects of cabbage and vitamin $E$ on colon carcinogenesis were investigated in Swiss mice treated with 1,2-dimethylhydrazine. Throughout the experiment the mice were fed a laboratory chow diet (46 mg vitamin $E$ per $\mathrm{kg}$ ) or chow containing $13 \mathrm{~g}$ cabbage per $100 \mathrm{~g}$ or $180 \mathrm{mg}$ vitamin $E$ per $\mathrm{kg}$. Starting after 31 days of diet treatment the mice received 7 weekly s.c. injections of DMH. They were sacrificed 17 weeks after the first dose of DMH. While diet did not significantly alter colon tumor response, some trends were observed. Female mice given cabbage had a higher incidence (percent of mice with a tumor) and multiplicity (tumors per tumor bearing mouse) of colon tumors. Males were little affected by cabbage apart from a lower incidence of adenocarcinomas. Compared with mice fed the control diet those given vitamin $\mathbf{E}$ had a higher colon tumor incidence. This effect, which was stronger in females, was due to an increased incidence of adenomas. Vitamin $\mathbf{E}$ had little apparent affect on tumor multiplicity apart from a reduction in adenocarcinomas in females and adenomas in males. The data do not support the view that cabbage and vitamin $E$ are protective against colon cancer.

\section{INTRODUCTION}

Several case-control studies have reported that cruciferous vegetables, paticularly cabbage, are eaten less frequently by patients with cancer of

Address for correspondence: Dr. Norman J. Temple, Department of Foods and Nutrition, 308 Home Economics Building, The University of Alberta, Edmonton, Alberta, Canada T6G 2M8 (Telephone: (403) 432-4925).

Address for reprints: Dr. S. El-Khatib, Puerto Rico (as above).

0304-3835/87/\$03.50 1987 Elsevier Scientific Publishers Ireland Ltd.

Printed and Published in Ireland 
the colon $[5,7,12]$. It was therefore of interest to determine whether this effect could be reproduced in an experimental model of colon carcinogenesis.

Whether vitamin $\mathrm{E}$ can prevent experimental cancer is still a matter of controversy $[3,4,6,8,17,23]$. One interpretation for these inconsistent results is the dose of vitamin used. It is possible that vitamin $E$ supplementation is effective at relatively low levels (200-600 $\mathrm{mg}$ per kg diet) but is ineffective when much larger doses are given. For instance, $500 \mathrm{mg}$ vitamin $\mathrm{E}$ per $\mathrm{kg}$ diet protected mice against transplanted sarcoma cells while a 10-fold higher.level was ineffective [9]. When mice were treated with DMH, fewer colon tumors were seen with $600 \mathrm{mg}$ vitamin $\mathrm{E}$ per $\mathrm{kg}$ diet than with $10 \mathrm{mg}$ per $\mathrm{kg}$ [2]. Similarly, in DMH treated rats vitamin E deficiency caused an accelerated appearance of colon tumors [19]. Conversely, $40 \mathrm{~g}$ vitamin $\mathrm{E}$ per $\mathrm{kg}$ diet increased colon tumor response in mice [21]. We therefore decided to examine the yield of colon tumors in mice fed diets adequate in or modestly supplemented with vitamin $\mathbf{E}$.

\section{MATERIALS AND METHODS}

\section{Mice and treatment}

Swiss mice were used from a colony maintained in our animal house. At an age of 5-7 weeks they were placed on the experimental diets (mean weight, g, S.D.: males $=29.54 .9$; females $=27.65 .5$ ). The diets were fed ad libitum until the experiment was terminated. Mice were housed in a temperature-controlled room with a 12-h light-dark cycle.

After 31 days on the experimental diets the mice were given the first of 7 weekly s.c. injections of DMH (Sigma Chemical Co., St. Louis, MO). This was dissolved in $1 \mathrm{mM}$ EDTA and neutralized with saturated sodium bicarbonate. The first dose was $23 \mathrm{mg} \mathrm{DMH} \cdot \mathrm{diHCl} / \mathrm{kg}$ body wt. followed by doses of 31,42 and then 4 doses of $56 \mathrm{mg} / \mathrm{kg}$. The use of a gradually rising dose is based on the observation that mice develop tolerance to DMH and thus allows the number of injections to be reduced while minimizing toxic effects [20].

\section{Diets}

Diet formulation is shown in Table 1 . Fresh food was given every 1-2 days.

\section{Tumor assessment}

Seventeen weeks after the first $\mathrm{DMH}$ injection, mice were sacrificed and internal organs grossly examined. The colon (including the cecum) was opened and carefully examined. Suspected tumors were removed and placed in neutral buffered formalin. They were confirmed after staining $(H \& E)[11,15]$. 
TABLE 1

COMPOSITION OF DIETS

\begin{tabular}{llll}
\hline Ingredients & \multicolumn{2}{c}{ Diet, composition by weight } \\
\cline { 2 - 4 } & Control & Cabbage & Vitamin E \\
\hline Chow $(\%)^{\mathrm{b}}$ & 100 & 87 & 100 \\
Cabbage $(\%)^{\mathrm{c}}$ & $\ldots$ & 13 & - \\
Vitamin $\mathrm{E}(\mathrm{mg} / \mathrm{kg})$ & $46^{\mathrm{d}}$ & 41 & $180^{\mathrm{e}}$ \\
\hline
\end{tabular}

a Composition is expressed on a dry weight basis, except cabbage which is weight before homogenization. In each case water was added to the diet $(900 \mathrm{ml} / \mathrm{kg} \mathrm{chow})$.

b Rodent laboratory chow meal (Ralston Purina Co., St. Louis, MO). The diet consists mainly of cereal and vegetable foods and contains $23.4 \%$ protein, $16 \%$ neutral detergent fiber, $5.5 \%$ fat and an adequate content of all nutrients. Physiological energy is 3300 $\mathrm{Kcal} / \mathrm{kg}$.

c Bought locally and homogenized in tap water using a blender.

d Chow contains $65 \mathrm{i}$,u, vitamin $\mathrm{E} / \mathrm{kg}$. We have assumed $1 \mathrm{mg}=1.4 \mathrm{i}$.u.

e The supplemental vitamin E ( $D-\alpha$-tocopherol acetate, Sigma) was dissolved in a small volume of ethanol.

The above procedures were carried out by observers who were unaware as to which dietary group the samples and mice had come from. Data were analyzed by two-tailed Student's $t$-test and by chi-square.

\section{RESULTS}

\section{DMH toxicity and body weight}

Six male mice on the vitamin $\mathrm{E}$ diet died ( $33 \%$ of the group). This occurred following the first injection. Other deaths during the period of injections were insignificant (2/83) but most groups manifested symptoms of mild toxicity, particularly weight loss of about 3-12\%. Diet did not affect weight gain or final body weight (Table 2).

\section{Tumor data}

The great majority of tumors were found in the mid- or distal-colon. Additionally, four were at the ileo-cecal junction. Diet had no apparent effect on the location of colon tumors. Two female, cabbage fed mice which had colon tumors, also had liver tumors.

Comparison of tumor data of mice fed diets supplemented with cabbage or vitamin $\mathrm{E}$ indicated no significant differences in comparison with the respective control groups. Nevertheless, certain trends are apparent. Cabbage supplemented female mice had a higher incidence (percent of mice with a tumor) and multiplicity (tumors per tumor bearing mouse) of colon tumors 
TABLE 2

EFFECT OF DIETARY CABBAGE AND VITAMIN E ON THE INCIDENCE AND TYPE OF COLON TUMORS IN MICE TREATED WITH DMH

Mice were sacrificed 17 weeks after the first dose of DMH.

\begin{tabular}{|c|c|c|c|c|c|c|c|c|c|}
\hline \multirow[t]{2}{*}{ Diet } & \multirow[t]{2}{*}{ Sex } & \multirow[t]{2}{*}{$\begin{array}{l}\text { No. of } \\
\text { mice }\end{array}$} & \multirow[t]{2}{*}{ Weight ${ }^{2}$} & \multicolumn{3}{|c|}{$\begin{array}{l}\% \text { of mice with colon tumors } \\
\text { (tumor incidence) }\end{array}$} & \multicolumn{3}{|c|}{$\begin{array}{l}\text { Colon tumors/tumor bearing mouse } \\
\text { (tumor multiplicity })^{\mathrm{a}}\end{array}$} \\
\hline & & & & Total & Adenoma & $\begin{array}{l}\text { Adeno- } \\
\text { carcinoma }\end{array}$ & Total & Adenoma & Adenocarcinoma \\
\hline Control & $\mathrm{F}$ & 14 & $37.4 \pm 3.5$ & 42.9 & 42.9 & 35.7 & $3.17 \pm 1.60$ & $2.17 \pm 1.17^{!}$ & $1.00 \pm 0.63$ \\
\hline Cabbage & $F$ & 16 & $35.5 \pm 3.5$ & $81.3^{b}$ & 62.5 & 68.7 & $4.92 \pm 4.41$ & $3.15 \pm 3.62$ & $1.77 \pm 1.42$ \\
\hline Vitamin $\mathbf{E}$ & $F$ & 15 & $38.1 \pm 3.4$ & 80.0 & 73.3 & 33.3 & $2.67 \pm 1.92$ & $2.25 \pm 2.13$ & $0.42 \pm 0.51$ \\
\hline Control & $\mathbf{M}$ & 17 & $39.8 \pm 2.6$ & 70.6 & 47.0 & 64.7 & $3.08 \pm 1.73$ & $1.92 \pm 1.51$ & $1.17 \pm 0.58$ \\
\hline Cabbage & M & 16 . & $39.3 \pm 3.9$ & 56.3 & 37.5 & 37.5 & $2.89 \pm 2.37$ & $1.78 \pm 2.05$ & $1.11 \pm 0.93$ \\
\hline Vitamin E & $\mathrm{M}$ & 11 & $38.3 \pm 3.5$ & 81.8 & 63.6 & 63.6 & $2.78 \pm 1.56$ & $1.44 \pm 1.23$ & $1.33 \pm 1.00$ \\
\hline
\end{tabular}

Values are mean \pm S.D.

h Two female colon tumor bearing mice also had a liver tumor. 
(Table 2). Cabbage feeding had little effect on males apart from causing an apparent fall in the incidence of adenocarcinomas.

Mice, particularly females, fed supplementary vitamin $E$ had a higher colon tumor incidence than those fed the control diet (Table 2). This was due to an increased incidence of adenomas rather than of adenocarcinomas. Tumor multiplicity was little affected by vitamin $\mathrm{E}$ except that there was a fall in adenocarcinomas in females and of adenomas in males.

\section{DISCUSSION}

The results presented here indicate that cabbage provides no protection against DMH induced colon tumors in mice. Indeed, in females there was actually a higher incidence and multiplicity of tumors when cabbage was given (not significant). The level of cabbage (13 $\mathrm{g}$ whole cabbage per $100 \mathrm{~g}$ diet, equivalent to $135 \mathrm{~g}$ per $2500 \mathrm{Kcals}$ ) was chosen so as to be comparable with the human situation. Our results therefore seem at variance with several case-control studies which have indicated that cabbage or related cruciferous vegetables may be protective against colon cancer [5,7,12].

Srisangnam et al. [18] also studied the effect of cabbage in DMH treated mice. In their model, tumors did not occur in the colon but were mainly in the spermatic cord followed by the liver and kidney. As in the experiment described here a low level of supplemental cabbage (10 or $20 \%$ dehydrated cabbage) caused an increase in tumor yield, albeit non-significant. However, a large cabbage intake ( $40 \%$ of diet) was protective.

Other evidence, apart from case-control studies, led us to expect that cabbage would be protective against experimental colon cancer. Wattenberg and others $[1,13,16,22]$ have shown that cabbage and related cruciferous vegetables induce xenobiotic-metabolizing enzymes in rodent liver and intestine (e.g. benzpyrene hydroxylase and aryl hydrocarbon hydroxylase). This is partly or wholly accounted for by the presence of various indole compounds $[10,13]$. In another study it was demonstrated that feeding of these chemicals prior to challenge with polycyclic aromatic hydrocarbon carcinogens inhibits subsequent neoplasia of mouse forestomach and rat mammary gland [24].

There are several possible explanations for our failure to observe any protective effect of cabbage against colon carcinogenesis. Firstly, our control diet was Rodent Chow. This contains alfalfa, which has similar properties to cruciferous vegetables as an inducer of xenobiotic-metabolizing enzymes $[1,16,22]$. The cabbage may therefore have been of no further benefit. Secondly, the enzymes induced by cabbage may not be relevant to DMH induced colon carcinogenesis. Thirdly, the level of cabbage may have been too low.

We were also surprised by the trend (not significant) for supplemental vitamin $\mathbf{E}$ to enhance colon carcinogenesis. This occurred particularly in females and was due to a rise in the incidence of adenomas. However, tumor 
multiplicity was lower in females for adenocarcinomas and in males for adenomas.

The level of supplementation used was modest (46 vs. $180 \mathrm{mg}$ per $\mathrm{kg}$ diet, equivalent to 35 vs $136 \mathrm{mg} / 2500 \mathrm{Kcal}$ as compared to a typical human intake of $8 \mathrm{mg} / 2500 \mathrm{Kcal}$ ). Thus the data does not support our hypothesis that vitamin $E$ in that dose range is anti-carcinogenic. Similar observations were recently reported by Reddy and Tanaka [14]. They observed that supplemented vitamin E (50 vs. $750 \mathrm{mg}$ per $\mathrm{kg}$ diet) did not affect the incidence of colon tumors in DMH treated rats but tended to increase tumor multiplicity. Possibly vitamin $\mathrm{E}$ is protective when the 'low' vitamin E diet is deficient or marginal, rather than nutritionally adequate as in our control diet. Such a possibility is consistent with other studies on $\mathrm{DMH}$ induced colon tumors in rodents. Thus vitamin $\mathbf{E}$ supplementation was protective in mice using a control diet containing only $10 \mathrm{mg}$ per $\mathrm{kg}$ [2] while in rats it delayed tumor appearance as compared to a deficient diet (under $5 \mathrm{mg}$ per kg) [19]. This should be further investigated.

\section{ACKNOWLEDGEMENTS}

The authors thank Mrs. Myma Nieves for skillful technical assistance, Mrs. Mabel Baaske, Mrs. Sandra Casovan and Mr. Arthur Stansfield for histological work and Dr. Lawrence Jewell (Department of Pathology, University Hospital, Edmonton) for advice on the interpretation of colon tumors. We also thank The Alberta Heritage Foundation for Medical Research for financial support.

\section{REFERENCES}

1 Bradfield, C.A., Chang, Y. and Bjeldanes, L.F. (1985) Effects of commonly consumed vegetables on hepatic xenobiotic-metabolizing enzymes in the mouse. Food Chem. Toxicol., 23, 899-904.

2 Cook, M.G. and McNamara, P. (1980) Effect of dietary vitamin E on dimethylhydrazine-induced colonic tumors in mice. Cancer Res., 40, 1329-1331.

3 Dayton, S., Hashimoto, S. and Wollman, J. (1977) Effect of high-oleic and highlinoleic safflower oils on mammary tumors induced in rats by 7,12-dimethylbenz( )anthracene. J. Nutr., 107, 1353-1360.

4 Epstein, S.S., Joshi, S., Andrea, J., Forsyth, J. and Mantel, N. (1967) The null effect of antioxidants on the carcinogenicity of $3,4,9,10$-dibenzpyrene to mice. Life Sci., 6, 225-233.

5 Graham, S. and Mettlin, C. (1979) Diet and colon cancer, Am, J. Epidemiol., 109, 1-20.

6 Haber, S.L. and Wissler, R.W. (1962) Effect of vitamin E on carcinogenicity of methylcholanthrene. Proc. Soc. Exp. Biol. Med., 111, 774-775.

7 Haenszel, W., Locke, F.B. and Segi, M. (1980) A case-control study of large bowel cancer in Japan. J. Natl. Cancer Inst., 64, 17-22.

8 Horvath, P.M. and Ip, C. (1983) Synergistic effect of vitamin $E$ and selenium in the chemoprevention of carcinogenesis in rats. Cancer Res., 43, 5335-5341. 
9 Kurek, M.P. and Corwin,L.M. (1982) Vitamin E protection against tumor formation by transplanted murine sarcoma cells. Nutr. Cancer 4, 128-139.

10 Loub, W.D., Wattenberg. L.W. and Davis, D.W. (1975) Aryl hydrocarbon hydroxylase induction in rat tissues by naturally occurring indoles of cruciferous plants. J. Natl. Cancer Inst., 54, 985-988.

11 Madara, J.L., Harte, P., Deasy, J., Ross, D., Lahey, S. and Steele, G. (1983) Evidence for an adenoma-carcinoma sequence in dimethylhydrazine-induced neoplasms of rat intestinal epithelium. Am. J. Pathol., 110, 230-235.

12 Manousos, O., Day, N.E., Trichopoulos, D., Gerovassilis, F., Tzonou, A. and Polychronopoulou, A. (1983) Diet and colorectal cancer: a case-control study in Greece. Int. J. Cancer, 32, 1-5.

13 Pantuck, E.J., Hsiao, K.-C., Loub, W.D., Wattenberg, L.W., Kuntzman, R. and Conney, A.H. (1976) Stimulatory effect of vegetables on intestinal drug metabolism in the rat. J. Pharmacol. Exp. Ther., 198, 278-283.

14 Reddy, B.S, and Tanaka, T. (1986) Interactions of selenium deficiency, vitamin E, polyunsaturated fat, and saturated fat on azoxymethane-induced colon carcinogenesis in male F 344 rats. J. Natl. Cancer Inst., 76, 1157-1162.

15 Robbins, S.H., Cotran, R.S. and Kumar, V. (1984) Pathologic Basis of Disease. pp. 218-220. Saunders, New York.

16 Salbe, A.D. and Bjeldanes, L.F. (1985) The effects of dietary Brussels sprouts and Schizandra chinensis on the xenobiotic-metabolizing enzymes of the rat small intestine. Food Chem. Toxicol., 23, 57-65.

17 Shklar, G. (1982) Oral mucosal carcinogenesis in hamsters: inhibition by vitamin $E$. J. Natl. Cancer Inst., 68, 791-797.

18 Srisangnam, C., Hendricks, D.G., Sharma, R.P., Salunkhe, D.K. and Mahoney, A.W. (1980) Effects of dietary cabbage (Brassica oleracea L.) on the tumorigenicity of 1,2-dimethylhydrazine in mice. J. Food Safety, 4, 235-245.

19 Sumiyoshi, H. (1985) Effects of vitamin E deficiency on 1,2-dimethyihydrazineinduced intestinal carcinogenesis in rats. Hiroshima J. Med. Sci., 34, 363-369.

20 Temple, N.J. and El-Khatib, S.M. (1985) Toxicity of 1,2-dimethylhydrazine in mice: effect of diet and development of tolerance. J. Food Safety, 7, 77-81.

21 Toth, B. and Patil, K. (1983) Enhancing ef fect of vitamin E on murine intestinal tumorigenesis by 1,2-dimethylhydrazine dihydrochloride. J. Natl. Cancer Inst., 70, $1107-1111$.

22 Wattenberg, L.W. (1971) Studies of polycyclic hydrocarbon hydroxylases of the intestine possibly related to cancer. Effect of diet on benzpyrene hydroxylase activity. Cancer $28,99-102$.

23 Wattenberg, L.W. (1972) Inhibition of carcinogenic and toxic effects of polycyclic hydrocarbons by phenolic antioxidants and ethoxyquin. J. Natl. Cancer Inst., 48, $1425-1430$.

24 Wattenberg, L.W, and Loub, W.D. (1978) Inhibition of polycyclic aromatic hydrocarbon-induced neoplasia by naturally occurring indoles. Cancer Res., 38, 14101413. 